\title{
Optimal use of the AUDIT in screening and brief intervention programs: a decision theoretic approach (part of Economics of SBI symposium)
}

\author{
Arnie Aldridge*, Will Parish \\ From INEBRIA 12th Congress, \\ Atlanda, GA, USA. 24-25 September 2015
}

\section{Background}

Current evidence suggests that screening and brief intervention (SBI) programs can be effective at reducing risky alcohol consumption. While validity and reliability have been demonstrated for existing screening instruments, little is known about how the diagnostic properties of an instrument influence the cost-effectiveness of SBI. We develop a decision theoretic framework to model this issue, and to measure the potential improvement in cost-effectiveness that could result from changes in screening instrument properties and other factors associated with SBI.

\section{Material and methods}

To make use of our decision theoretic model, we obtain estimates of the input parameters by conducting a comprehensive review of the literature. In particular, we review the literature on the sensitivity and specificity of the Alcohol Use Disorders Identification Test (AUDIT), and then synthesize this evidence using meta-analytic methods. We also compile evidence on the cost of SBI, the QALY gains of SBI, and the prevalence of risky drinking among primary care patients. We assess uncertainty via Monte Carlo analysis. Finally, we conduct expected value of perfect information (EVPI) analyses to investigate the sources of decision uncertainty.

\section{Results}

When QALYs are valued at a conservative \$1,000/QALY our decision theory indicates an optimal AUDIT threshold score of 5. Our model indicates that employing the recommended threshold score of 8 results in about $\$ 4.50$ per patient in foregone benefits. This suggests large aggregate

\footnotetext{
* Correspondence: aaldridge@rti.org
} RTI International, RTP, USA
Cite this article as: Aldridge and Parish: Optimal use of the AUDIT in screening and brief intervention programs: a decision theoretic Clinical Practice 2015 10(Suppl 2):O1.

Submit your next manuscript to BioMed Central and take full advantage of:

- Convenient online submission

- Thorough peer review

- No space constraints or color figure charges

- Immediate publication on acceptance

- Inclusion in PubMed, CAS, Scopus and Google Scholar

- Research which is freely available for redistribution approach (part of Economics of SBI symposium). Addiction Science \& 